Conflicts of interest. All authors report no conflicts of interest relevant to this article.

\section{References}

1. Kappe T, Cakir B, Mattes T, Reichel H, Flören M. Infections after bone allograft surgery: a prospective study by a hospital bone bank using frozen femoral heads from living donors. Cell Tissue Bank 2010;11:253-259.

2. Tomford WW, Thongphuasuk J, Mankin HJ, Ferraro MJ. Frozen musculoskeletal allografts: a study of the clinical incidence and causes of infection associated with their use. J Bone Joint Surg (Am) 1990;72:1137-1143.

3. Journeaux SF, Johnson N, Bryce SL, Friedman SJ, Sommerville SM, Morgan DA (1999) Bacterial contamination rates during bone allograft retrieval. J Arthroplasty 1999;14:677-681.

4. Barnhart B, Allan DG, Milbrandt JC, Khardori N, Hall A, Barenfanger J. Intra-operative culturing of donor allograft bone: a lack of clinical utility. U Pa Orthop J 2009;19.
5. Pruss A, Seibold M, Benedix F, et al. Validation of the Marburg bone bank system for thermodisinfection of allogenic femoral head transplants using selected bacteria, fungi, and spores. Biologicals 2003;31:287-294.

6. Anderson DJ, Perl TM. Basics of surgical site infection: surveillance and prevention. In: Lautenbach E, et al, editors. Practical Healthcare Epidemiology, 4th edition. Cambridge: Cambridge University Press; 2018:147-161.

7. The Canadian Council for Donation and Transplantation (CCDT). Evaluation of surgical bone banking and utilization in Canada 2006; 19. https://profedu.blood.ca/sites/msi/files/Surgical-Bone.pdf.

8. Nielsen HT, Larsen S, Andersen M, Ovesen O. Bone bank service in Odense, Denmark. Audit of the first ten years with bone banking at the Department of Orthopaedics, Odense University Hospital. Cell Tissue Bank 2001;2: 179-183.

9. Fu S-H, Liu J-Y, Huang C-C, Lin F-l, Yang R-S, Hou C-H. Quality control processes in allografting: A twenty-year retrospective review of a hospitalbased bone bank in Taiwan. PLoS One 2017;12(10):e0184809.

\title{
Estimating coronavirus disease 2019 (COVID-19)-caused deaths in hospitals and healthcare units: Do hospital-acquired infections play a role? Comments with a proposal
}

\author{
Salvatore Chirumbolo $\mathrm{PhD}^{1}$ (1), Vincenzo Simonetti $\mathrm{MD}^{2}$ (1) , Marianno Franzini $\mathrm{MD}^{3,4}$, Luigi Valdenassi $\mathrm{MD}^{3,4}$, \\ Dario Bertossi MD ${ }^{5}$ (i) and Sergio Pandolfi MD ${ }^{3,4}$ \\ ${ }^{1}$ Department of Neurosciences, Biomedicine and Movement Sciences, University of Verona, Verona, Italy, ${ }^{2}$ Oxygen-Ozone Therapy Scientific Society (SIOOT), \\ Gorle, Italy, ${ }^{3} \mathrm{SIOOT}$, High School in Oxygen Ozone Therapy, University of Pavia, Italy, ${ }^{4} \mathrm{SIOOT}$ International, Community Clinic, Gorle Bergamo, Italy and \\ ${ }^{5}$ Department of Surgery, Dentistry, Pediatrics and Gynecology Unit of Maxillo-Facial Surgery, University of Verona, Verona, Italy
}

To the Editor-A recent paper by Giacobbe et a ${ }^{1}$ reported that 171 of 586 patients (29\%) (mean age, 64 years) hospitalized for coronavirus disease 2019 (COVID-19) in intensive care units (ICUs) of major Italian hospitals also had ventilator-associated pneumonia (VAP) caused by superinfection, mainly with Pseudomonas aeruginosa (35\%) and Staphylococcus aureus (23\%). These authors reported that the 30 -day case fatality caused by VAP was $46 \%$ (77 of 171). Furthermore, in multivariate analysis, the odds ratio (OR) of septic shock on VAP onset was 3.30 (95\% CI, 1.43$7.61 ; P=.005)$ and the OR of acute respiratory distress syndrome (ARDS) was 13.21 (95\% CI, 3.05-57.26; $P<.001)$. Both were associated with mortality. ${ }^{1}$ These authors collected bronchoalveolar lavage fluid (BALF) from 79 of 171 patients and reported positive microbial cultures in 77 of 79 BALFs (97\%). ${ }^{1}$

Hospital-acquired infections (HAIs) are a huge concern for hospitals in Italy. A survey by Lizioli et $\mathrm{al}^{2}$ revealed that most HAIs in Lombardy, the Italian region with the most COVID-19 deaths, occurred in ICUs. The high prevalence of HAIs in ICUs in Italy has also been reported by other authors ${ }^{3,4}$ who associated such infections with the use of urinary catheter, surgical drainage, and intravascular catheters, as well as mechanical ventilation. ${ }^{4}$

Author for correspondence: Prof Salvatore Chirumbolo, E-mail: salvatore. chirumbolo@univr.it

Cite this article: Chirumbolo S, et al. (2022). Estimating coronavirus disease 2019 (COVID-19)-caused deaths in hospitals and healthcare units: Do hospital-acquired infections play a role? Comments with a proposal. Infection Control \& Hospital Epidemiology, 43: 810-811, https://doi.org/10.1017/ice.2021.122
A major COVID-19 concern has been widely associated with activity in ICUs. Lockdown policy and restrictions in social habits have been implemented to decrease the burden of hospitalized people in ICUs. However, despite several reports in the literature, ${ }^{5,6}$ a sound public debate about HAIs, particularly among elderly people with severe comorbidities, has not been addressed by politicians or journalists in Italy. Furthermore, neither a proper democratic debate nor a political discussion has included more suitable and effective protocols aimed toward greatly reducing the impact of HAIs in ICUs among COVID-19 patients. Thus far, the public debate has included issues regarding social contacts and severe acute respiratory coronavirus virus 2 (SARS-CoV-2) infection in the general population, but HAIs have not been adequately considered. Undoubtedly, the dramatic increase in COVID-19 deaths includes HAI coinfection cases. We aimed to calculate a more correct estimation of these cases using data from Italian Ministry of Health that were publicly available online on February 14, 2021. Among the entire COVID-19-positive population (2,721,879 people), 2,085 patients went to an ICU and 382,249 did not need hospitalization (good outcome-group 1); 93,577 patients died and 2,275,519 individuals were discharged or healed from the infection (good outcome-group 2). The relative risk (RR) of dying in an ICU from COVID-19 was 7.28, with an OR of 7.54 (95\% confidence interval [CI], 7.22-7.87). However, the RR of dying from an HAI coinfection was 24.59 , and the rate of VAPassociated death may be as low as $13.34 \%^{1}$ with an OR of 28.22 (95\% CI, 26.93-29.58). HAIs represent a 4 -fold RR of dying during 
a COVID-19 ICU hospitalization compared to COVID-19 patients who recover, are discharged, or reach RT-PCR swab negativity, which account for at least $81.76 \%$ of all COVID-19 patients.

A very recent report showed that gram-negative bacteria, more than SARS-CoV-2, are detectable in ICUs, particularly in sinks and siphons, compared to the absence of SARS-CoV2 on surfaces and instruments in the ICU environment. ${ }^{7}$ This finding suggests that a correct sanitization protocol is particularly crucial. Ozone, for example, can dampen completely gramnegative bacteria, such as $P$. aeruginosa, to an extent comparable to chlorhexidine. ${ }^{8}$ Notably, Hanifi et $\mathrm{al}^{9}$ reported the ability of ozonated water and chlorhexidine gluconate to reduce VAP. This report assessed further evidence showing the ability of gaseous ozone and ozonized water to completely remove SARSCoV-2 contamination from any surface. ${ }^{10}$ These authors addressed oral care with ozonated water in 39 patients and with chlorhexidine gluconate in 35 patients to reduce VAP incidence. Patients were $67.57 \%$ men and $32.43 \%$ women, aged between 18 and 68 years, and $\sim 63.51 \%$ were admitted to ICUs. These authors concluded that ozone was more effective in reducing VAP than chlorhexidine. ${ }^{9}$ Usual detergents and disinfectants can reduce $P$. aeruginosa on surfaces from 1.17 to $1.63 \mathrm{log}$ (ie, from $92.93 \%$ to $97.31 \% \mathrm{CFU} / \mathrm{cm}^{2}$ ), whereas ozone reduced bacterial biofilms to $7.34 \log \left(99.99999 \% \mathrm{CFU} / \mathrm{cm}^{2}\right) .{ }^{8}$ Ozone, in particular, enables complete environmental clearance of SARS$\mathrm{CoV} 2$ viral particles. A plaque test of VERO-E6/TMPRSS2 cells infected with SARS-CoV2, performed by Yano et al, ${ }^{11}$ calculated that $1.0 \mathrm{ppm}$ ozone treatment for 60 minutes reduced the viral presence in the cell lines from $1.7 \times 10^{7} \mathrm{PFU} / \mathrm{mL}$ to $1.7 \times 10^{4}$ $\mathrm{PFU} / \mathrm{mL}$, whereas controls were reduced to $5.8 \times 10^{5}$ $\mathrm{PFU} / \mathrm{mL}$. With $6 \mathrm{ppm}$ ozone for 55 minutes, the reduction reached $1.0 \times 10^{3} \mathrm{PFU} / \mathrm{mL}$ and only $2.0 \times 10^{6}$ for the control. ${ }^{11}$

A correct policy of sanitization in ICUs is mandatory to reduce deaths in these areas and to shift the awkward burden of lockdown to an improved policy of hospital service and healthcare management supported by physicians and care givers. The impact of HAIs can be easily dampened by widespread use of ozone in ICUs, a product that usually degrades into molecular oxygen and has low toxicity compared to other sanitization products. To significantly reduce deaths from COVID-19, political discourse must give attention to the urgent breakdowns that result in HAIs in hospitals and ICUs concurrent with COVID-19.

Acknowledgments. A special thank to the SIOOT organizing Committee.

Financial support. No financial support was provided relevant to this article.

Conflicts of interest. All authors report no conflicts of interest relevant to this article.

\section{References}

1. Giacobbe DR, Battaglini D, Enrile EM, et al. Incidence and prognosis of ventilator-associated pneumonia in critically ill patients with COVID-19: a multicenter study. J Clin Med 2021;10:555.

2. Lizioli A, Privitera G, Alliata E, et al. Prevalence of nosocomial infections in Italy: result from the Lombardy survey in 2000. J Hosp Infect 2003;54:141-148.

3. Nicastri E, Petrosillo N, Martini L, et al. Prevalence of nosocomial infections in 15 Italian hospitals: first point prevalence study for the INF-NOS project. Infection 2003;31 suppl 2:10-15.

4. Zotti CM, Messori Ioli G, Charrier L, et al. Hospital-acquired infections in Italy: a region wide prevalence study. J Hosp Infect 2004;56:142-149.

5. Bardi T, Pintado V, Gomez-Rojo M, et al. Nosocomial infections associated to COVID-19 in the intensive care unit: clinical characteristics and outcome. Eur J Clin Microbiol Infect Dis 2021;40:495-502.

6. Maes M, Higginson E, Pereira-Dias J, et al. Ventilator-associated pneumonia in critically ill patients with COVID-19. Crit Care 2021;25:25.

7. Hofmaenner DA, Wendel Garcia PD, Duvnjak B, et al. Bacterial but no SARS-CoV-2 contamination after terminal disinfection of tertiary-care intensive care units treating COVID-19 patients. Antimicrob Resist Infect Control 2021;10:11.

8. Oliver JC, Bredarioli PAP, Leandro FD, Ferreira CBRJ, Veiga SMOM, Dias ALT. Ozone against Pseudomonas aeruginosa biofilms in contact lenses storage cases. Rev Inst Med Trop Sao Paulo 2019;61:e23.

9. Hanifi N, Masoumi M, Reza Jamshidi M, Faghihzadeh S. The effect of ozonated water and chlorehixidine gluconate on prevention of ventilator-associated pneumonia: a double blind, randomized, clinical trial Iran Red Crescent Med J 2107;19:e60576.

10. Murata T, Komoto S, Iwahori S, et al. Reduction of severe acute respiratory syndrome coronavirus-2 infectivity by admissible concentration of ozone gas and water. Microbiol Immunol 2020. doi: 10.1111/1348-0421.12861.

11. Yano H, Nakano R, Suzuki Y, Nakano A, Kasahara K, Hosoi H. Inactivation of severe acute respiratory syndrome coronavirus 2 (SARS-CoV-2) by gaseous ozone treatment. J Hosp Infect 2020;106:837-838.

\title{
High mortality in coronavirus disease 2019 (COVID-19)-suspect unit: Lessons learned for patient safety
}

\author{
Anucha Apisarnthanarak MD ${ }^{1}\left(\mathbb{0}\right.$, Surachai Chaononghin $\mathrm{MD}^{1}$, Panipak Katawethiwong $\mathrm{MD}^{1}$ and \\ David K. Warren MD² \\ ${ }^{1}$ Division of Infectious Diseases, Thammasat University Hospital, Pratum Thani, Thailand and ${ }^{2}$ Division of Infectious Diseases, Washington University School of \\ Medicine, Saint Louis, Missouri
}

\footnotetext{
Author for correspondence: Anucha Apisarnthanrak, E-mail: anapisarn@yahoo.com Cite this article: Apisarnthanarak A, et al. (2022). High mortality in coronavirus disease 2019 (COVID-19)-suspect unit: Lessons learned for patient safety. Infection Control \& Hospital Epidemiology, 43: 811-813, https://doi.org/10.1017/ice.2021.91
}

To the Editor-The coronavirus disease 2019 (COVID-19) pandemic is a global healthcare emergency on a scale not seen in more than a century. With the emergence of new variants, COVID-19 is becoming potentially more contagious with transmission dynamics

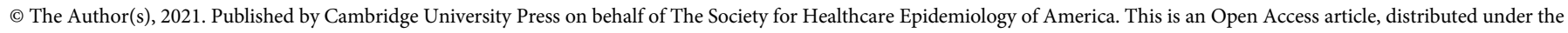
terms of the Creative Commons Attribution licence (http://creativecommons.org/licenses/by/4.0/), which permits unrestricted re-use, distribution, and reproduction in any medium, provided the original work is properly cited. 